*Discente do $7^{\circ}$ termo de curso de Direito do Centro Universitário Antônio Eufrásio de Toledo de Presidente Prudente, bolsista do $\mathrm{CNPq}$ na modalidade de pesquisador de iniciação cientifica. E-mail: joel.bercocano1425@ gmail.com.

**Doutor e Mestre em Sistema Constitucional de Garantias pela Instituição Toledo de Ensino - ITE de Bauru. Professor do Mestrado e Doutorado da mesma instituição. Mestre em Direito das Relações Sociais pela Unimar. Especialista em interesses difusos pela Escola Superior do Ministério PúblicoSP. Coordenador da Faculdade de Direito de Presidente Prudente / FDPP do Centro Universitário Antonio Eufrásio de Toledo e professor titular da disciplina de Teoria Geral do Estado e Direito Internacional e Direitos Humanos da FDPP. Membro da Asociación Colombiana de DerechoProcesal Constitucional e daAsociaón Mundial de Justicia Constitucional. Coordenador de pesquisa do CNPq_E-mail:coord.direito@, toledoprudente.edu.br ou sergio@ unitoledo.br

\section{PRECEDENTES COMO INSTRUMENTO DE EFETIVAÇÃO DE SEGURANÇA JURÍDICA}

\author{
Joel Vieira Berçocano* \\ Sérgio Tibiriçá Amaral**
}

Como citar: BERÇOCANO, Joel Vieira; AMARAL, Sérgio Tibiriça. PRECEDENTES COMO INSTRUMENTO DE EFETIVAÇÃO DE SEGURANÇA JURÍDICA. Revista do Instituto de Direito Constitucional e Cidadania - IDCC, Londrina, v. 4, n. 1, p 117-134, ago, 2019. ISSN: 2596-0075. https://doi.org/10.48159/revistadoidcc.v4n1.berçocano.amaral 


\section{INTRODUÇÃO}

Através do meio indutivo, esse artigo buscou expor o funcionamento do microssistema de precedentes no Brasil tendo por enfoque a sua aplicação os tribunais de sobreposição.

Foram feitas singelas comparações entre o Código de Processo Civil de 2015 e o Código de Processo Civil de 1973, de forma a demonstrar as principais alterações inauguradas pelo novel Código.

No primeiro tópico foi apresentada uma ideia geral do que se entende por microssistema de precedentes, sendo relatado os motivos que deram gênese a tais instrumentos. Bem como a importância que o Processo Civil lhes concedeu ao promulgar o Código de Processo Civil de 2015.

Nos subtópicos relativos ao Microssistema de Precedentes foram tratadas as principais espécies de precedentes obrigatórios. Tendo por enfoque a sua aplicação feita pelos tribunais de sobreposição.

No terceiro tópico dessa obra foi conceituado o que se deve entender por segurança jurídica, e as razões pela qual deve ser considerada um princípio fundamental, que balize as decisões dos tribunais e juízes monocráticos.

No tópico concernente à solipsismo judicial foram expostos seus principais celeumas e falhas. Também foi revelado que o ativismo judicial baseado em uma aplicação incorreta da teoria dos princípios, é contestado por seu maior representante, qual seja Humberto Ávila.

Por fim, este estudo arguiu a efetividade do microssistema de precedentes no combate ao solipsismo judicial e a consequente efetivação do princípio da segurança jurídica.

\section{O MICROSSISTEMA DOS PRECEDENTES}

Antes de analisar o sistema de precedentes propriamente dito é importante conceituar o que se entende por precedente, distinguindo-o da jurisprudência. A melhor doutrina faz a distinção da seguinte forma:

O termo "jurisprudência" traz ínsita a ideia de pluralidade, ou seja, de um conjunto de decisões judiciais a respeito de determinada matéria jurídica. Daí a distinção entre precedente e jurisprudência. Enquanto o termo jurisprudência designa um grupo de decisões, o termo "precedente" espelha, por essência, uma única e relevante decisão judicial. Tal relevância decorre, normalmente, da profundidade da discussão a respeito do tema e da capacidade desse entendimento influenciar decisões futuras. ${ }^{1}$

1 PINHEIRO, Paulo Eduardo D’Arce et al. Curso de processo civil completo. São Paulo: Revista dos Tribunais, 2017 p. 58 
A distinção é importante pois a jurisprudência sempre foi aceita pela doutrina brasileira como fonte mediata de direito. Enquanto os precedentes estão ganhando paulatinamente o reconhecimento como fonte do direito, sendo que, apenas em 2015, com o Novo Código de Processo Civil, que a lei processual civil trouxe um sistema de microssistema de precedentes bem estruturado.

O Código de Processo Civil de 2015 no seu artigo art.489, $§ 1^{\circ}$ VI determina que considera-se não fundamentada a sentença que: "deixar de seguir enunciado de súmula, jurisprudência ou precedente invocado pela parte, sem demonstrar a existência de distinção no caso em julgamento ou separação do entendimento". ${ }^{2}$ O referido artigo deixa claro a importância que o Código de processo Civil deu aos precedentes.Esse e outros artigos do referido Diploma Legal embasaram o enunciado 380 do Fórum Permanente de Processualistas Civis, o qual tem a seguinte redação: “(arts. 8, 926, 927) A expressão “ordenamento jurídico”, empregada pelo Código de Processo Civil, contempla os precedentes vinculantes." Questão interessante é que o precedente é o resultado da norma geral e abstrata aplicada ao caso concreto, o que por sua vez faz lei entre as partes.Esse entendimento é pacífico na doutrina. ${ }^{3} \mathrm{O}$ disruptivo Código consagrou um sistema processual em que uma única decisão isolada, desde que atenda a alguns requisitos, tem o condão de uniformizar a jurisprudência de todo um país. A uniformização das decisões é um objetivo a ser alcançado, pois segundo a doutrina, é através dela que é atingida a segurança jurídica.Nesse sentido é pensar Daniel Amorim Assumpção Neves:

Como ensina a melhor doutrina, a uniformização de jurisprudência atende à segurança jurídica, à previsibilidade, à estabilidade, ao desestímulo à litigância excessiva, à confiança, à igualdade perante a jurisdição, à coerência, ao respeito à hierarquia, à imparcialidade, ao favorecimento de acordos, à economia processual (de processos e de despesas) e à maior eficiência. ${ }^{4}$

Essas alterações legais, romperam não apenas com velhos dogmas do processo civil, alteraram parte importante da teoria geral do direito, qual seja, as fontes do direito, na medida em que um único caso pode ser fonte de direito, e mais ainda, pode vincular todo o ordenamento jurídico.

O Código de Processo Civil, dispõe de diversos meios que compõem o microssistema de precedentes. O sistema de precedentes está dividido em todas as instâncias do Poder Judiciário brasileiro, mas também é encontrado em outros países da civil low. Nos tópicos subsequentes serão tratadas as principais espécies de precedentes previstas no Código de Processo Civil brasileiro.

2 BRASIL, Código de Processo Civil, Lei 13.105/2015.

3 KELSEN, Hans; Teoria pura do direito. Tradução MACHADO, João Batista - 8 . Ed. - São Paulo: Editora WMF Martins Fontes, 2009 p.263/264

4 NEVES, Daniel Amorim Assumpção. Manual de direito processual civil: volume único. 9. ed., rev., e atual. São Paulo: Método, 2017 p. 1392/1393 


\section{INCIDENTE DE ASSUNÇÃO DE COMPETENCIA}

O incidente de assunção está previsto no art.947 CPC/15, o qual define que esse será cabível quando:

Art. 947. É admissível a assunção de competência quando o julgamento de recurso, de remessa necessária ou de processo de competência originária envolver relevante questão de direito, com grande repercussão social, sem repetição em múltiplos processos [...].

$\S 4$-Aplica-se o disposto neste artigo quando ocorrer relevante questão de direito a respeito da qual seja conveniente a prevenção ou a composição de divergência entre câmaras ou turmas do tribunal. ${ }^{5}$

Atente-se para o fato que a Lei possibilita que o incidente seja instaurado em recurso, remessa necessária ou em processo de competência originária do tribunal. O que significa dizer que o incidente de assunção de competência pode ser instaurado de ofício pela autoridade judicante, pois a remessa necessária decorre da lei e não da vontade das partes, razão pela qual no mais das vezes essas não se manifestam no órgão colegiado. Isso aclarei-a a ideia de que o incidente de assunção de competência transcende os interesses dos litigantes, pois tem o condão de produzir efeitos erga omnes.

A letra da lei elenca a "grande repercussão social" como um dos requisitos para a admissão do incidente de assunção de competência. Por essa razão, é imprescindível saber o que se entende por repercussão social ou repercussão geral. O conceito legal está no art. 1.035, $\S 1^{\circ} \mathrm{CPC} / 15^{6}$. A doutrina, por sua vez, ao conceitua repercussão geral da seguinte forma:

Por repercussão geral, a lei entende que se origina de questões "que ultrapassem os interesses subjetivos do processo", por envolver controvérsias que vão além do direito individual ou pessoal das partes. É preciso que, objetivamente, econômico, político, social ou jurídico" $\left(\operatorname{art} .1 .035, \S 1^{\circ}\right) .^{7}$

A Lei faz tal exigência, pois, diferentemente de outros procedimentos, o incidente de assunção de competência não faz coisa julgada apenas inter partes, uma vez que o precedente que desse resulta tem eficácia vinculante e por essa razão interfere em todos os demais processos que discutem a mesma matéria.Tanto que as decisões que abordarem o assunto decidido em sede de incidente de assunção de competência, deverão obrigatoriamente segui-los ou demonstrar que o entendimento já fora superado, ou ainda que o caso sub judice não difere no caso que deu origem

5 BRASIL, Código de Processo Civil Lei 13.105/2015

6 BRASIL, Código de Processo Civil Lei 13.105/2015 Para efeito de repercussão geral, será considerada a existência ou não de questões relevantes do ponto de vista econômico, político, social ou jurídico que ultrapassem os interesses subjetivos do processo.

7 THEODORO JÚNIOR, Humberto. Curso de direito processual civil: volume 3 : execução forçada: cumprimento de sentença, execução de títulos extrajudiciais, processos nos tribunais, recursos, direito intertemporal. 50. ed., rev., atual., ampl. Rio de Janeiro: Forense, Gen, 2017 
ao precedente de eficácia vinculante, vide art.489, $\S 1^{\circ}, \mathrm{VI} \mathrm{CPC} / 15 .^{8}$

O outro requisito elencado pelo art.947 CPC é a falta de repetição em múltiplos processos. O que se perquire é o que deve ser entendido por "sem repetição".O tema é relevante, pois em uma interpretação ipsis literis, pode-se chegar à conclusão de que a questão suscitada para que tenha acolhida nesse instrumento processual precisará ser inédita e ter repercussão geral. Em que pese a falta de clareza do respectivo dispositivo legal a doutrina interpreta que por "sem repetição em múltiplos processos" deva-se entender por impossibilidade de instaurar IRDR (Incidente de Resolução de Demandas Repetitivas), nesse sentido:

De qualquer forma, parece acertada a conclusão do Enunciado 334 do Fórum Permanente de Processualista Civis (FPPC): "Por força da expressão 'sem repetição em diversos processos', não cabe o incidente de assunção de competência quando couber julgamento de casos repetitivos".

E o $\S 4 .^{\circ}$ do artigo ora comentado específica mais uma hipótese de cabimento do incidente ao prever a assunção de competência quando ocorrer relevante questão de direito a respeito da qual seja conveniente a prevenção ou a composição de divergência entre câmaras ou turmas do tribunal.

A par disso, o objetivo do legislador parece claro: criar um incidente em processos únicos ou raros de alta relevância social, até porque, se houver a multiplicidade de processos com a mesma matéria jurídica, existirão outros instrumentos processuais para se atingir o objetivo do incidente de assunção de competência. ${ }^{9}$

Dessa feita, o referido incidente cobre a lacuna deixada pelo IRDR (Incidente de Resolução de Demandas Repetitivas), visto que esse se preza a resolver questão de direito suscitada em repetidas e numerosas demandas. Isso equivale a dizer que a possibilidade de instaurar um incidente para criar um precedente de eficácia vinculante depende apenas da repercussão geral ou social, sendo que a repetição ou não, de múltiplas demandas indicará qual o instrumento apropriado para originar o precedente.

O incidente de assunção de competência tem por origem um processo que já se encontre em um órgão colegiado, seja por meio de recurso, remessa necessária ou competência originária.A razão disso é que o incidente transfere a causa do órgão colegiado fracionário para o pleno o qual será competente para decidir a causa e fixar o precedente. Essa dupla função do incidente foi inaugurada pelo Código de Processo Civil de 2015, o revogado Código de 1973 nos seus artigos 476 a 479 previa o correspondente do incidente ora tratado, tal instrumento era nominado de incidente de uniformização de jurisprudência.

No revogado incidente de uniformização de jurisprudência, o órgão pleno fixava a tese e o órgão fracionário julgava o recurso, reexame ou processo de

8 BRASIL, Código de Processo Civil Lei 13.105/2015 § 1o Não se considera fundamentada qualquer decisão judicial, seja ela interlocutória, sentença ou acórdão, que:

VI - deixar de seguir enunciado de súmula, jurisprudência ou precedente invocado pela parte, sem demonstrar a existência de distinção no caso em julgamento ou a superação do entendimento.

9 NEVES, Daniel Amorim Assumpção. Novo código de processo civil: comentado artigo por artigo. 2.ed., rev. e atual. Salvador, BA: JusPODIVM, 2017 p 947 
competência originária aplicando-a. No incidente de assunção de competência o próprio recurso, reexame necessário ou processo de competência originária é ncaminhado para o órgão pleno, que terá dupla missão: julgá-los e fixar a tese. ${ }^{10}$

Essa alteração legislativa, vai ao encontro do princípio da isonomia e da celeridade e economia dos atos processuais. É isonômico, pois não será possível haver disparidade entre o que for decidido na causa original (inter partes) e seu precedente de eficácia vinculante (eficácia erga omnes); é célere, pois concentra a resolução da demanda em um único colegial, pela mesma razão economiza os atos processuais uma vez que será prolatada uma única decisão.

\section{INCIDENTE DE ARGUIÇÃO DE INCONSTITUCIONALIDADE}

O incidente de arguição de inconstitucionalidade já era figura conhecida do sistema processual brasileiro, era previsto no art. 480 CPC/73. O chamado incidente de arguição de inconstitucionalidade é a forma adequada de questionar a constitucionalidade de lei ou ato normativo do poder público pela via difusa. Ou seja, é o controle de constitucionalidade aplicado aos casos concretos e que por sua vez o seu julgado produz apenas efeitos inter partes. A melhor doutrina explica a inconstitucionalidade como sendo uma ofensa à Constituição Federal

Mas tanto a constitucionalidade como a inconstitucionalidade pressupõem a existência de uma constituição rígida, dotada de supremacia formal, cujas normas sirvam de parâmetro para a elaboração das demais prescrições do ordenamento jurídico $\{\ldots\}$

Na inconstitucionalidade ferem-se preceitos da constituição - a norma hierárquica máxima do ordenamento jurídico. ${ }^{11}$

Tal observação se faz necessária pois Brasil é adapto tanto do modelo americano de controle de constitucionalidade (controle difuso), quanto do modelo europeu de controle de constitucionalidade (controle concentrado). O controle abstrato produz efeitos erga omnes enquanto o difuso em regra produz efeitos inter partes, mas tem o condão de, observadas algumas condições, produzir efeitos erga omnes tal qual o modelo europeu.

Neste trabalho teremos por enfoque o controle difuso em especial o realizado por tribunais, a se entender por órgãos colegiados, pois são esses que podem pela via difusa dar gênese a precedentes de eficácia vinculante.

A arguição de inconstitucionalidade é questão prejudicial, o que equivale a dizer que enquanto não for superada a discussão da inconstitucionalidade não poderá ser analisado o mérito da causa. Portanto a arguição de inconstitucionalidade não passa de uma tese para defender os interesses de quem a invoca. Por essa razão, a decisão sobre a validade ou invalidade

10 NEVES, Daniel Amorim Assumpção. Manual de direito processual civil: volume único. 9. ed., rev., e atual. São Paulo: Método, 2017 p. 1435

11 BULOS, UadiLammêgo. Curso de direito constitucional. 5. ed., ref. e atual. São Paulo: Saraiva, 2010 p 133 e 134 
constitucional da lei ou ato normativo não põe fim ao processo, é possível que o réu que alegou a inconstitucionalidade se veja livre da sucumbência por outras razões que não a inconstitucionalidade (desistência, reconhecimento da inexigibilidade da dívida entre outros).

Além de ser questão prejudicial, a constitucionalidade por se tratar de matéria de ordem pública, não sujeita à preclusão, a doutrina entende que a legitimidade para a interposição do incidente é ampla, nesse sentido Daniel Amorim Assumpção Neves diz que:

Como não existe previsão a respeito da legitimidade ativa para a suscitação do incidente de arguição de inconstitucionalidade, entende-se pela legitimidade ampla. Não poderia ser de outra forma, já que o incidente pode ser instaurado de ofício, e se pode ser instaurado de ofício, pode a instauração decorrer de provocação de qualquer sujeito processual. São, portanto, legitimadas as partes e terceiros intervenientes do processo, o Ministério Público nos processos em que participa como fiscal da ordem jurídica, a Defensoria Pública, nos processos dos quais participe e os juízes que integram o colegiado. ${ }^{12}$

Portanto, a legitimidade analisada de per si, não obsta a arguição do incidente. Contudo outras questões devem ser analisadas para que o incidente tenha acolhida pelo pleno ou órgão pleno do tribunal que analisará a questão.

Entretanto, outros requisitos devem ser analisados para decidir pelo cabimento ou não cabimento do incidente ora em comento. As hipóteses de não cabimento do incidente encontram-se no art.949 Parágrafo único do CPC/15, o qual prescreve que:

Os órgãos fracionários dos tribunais não submeterão ao plenário ou ao órgão especial a arguição de inconstitucionalidade quando já houver pronunciamento destes ou do plenário do Supremo Tribunal Federal sobre a questão. ${ }^{13}$

A razão disso é a valorização da reserva de plenário e das decisões do STF que é o guardião da Constituição Federal e intérprete máximo do texto constitucional. No entanto, uma observação há que ser feita, parte da doutrina entende que o referido texto não deve ser interpretado de forma ipsis literis, pois defendem que as decisões do STF em controle difuso não tem o condão de uniformizar a jurisprudência, pois só produzem efeitos inter partes.

Para essa parcela da doutrina, tendo sido a declaração de inconstitucionalidade pelo Supremo Tribunal Federal realizada de forma incidental, a eficácia dessa declaração é inter partes, de forma que ninguém estará vinculado a essa decisão, nem mesmo o tribunal de segundo grau ou o Superior Tribunal de Justiça. O Supremo Tribunal Federal, entretanto, aplica a regra em sua literalidade, admitindo a dispensa do incidente processual quando por meio de seu plenáriojá tenha declarado, mesmo incidentemente, a inconstitucionalidade da norma (STF, $1^{\circ}$ Turma, RE 370.765 AgR/RS, rel.Min. Marco Aurélio, j. 08/02/2011, DJe

12 NEVES, Daniel Amorim Assumpção. Novo código de processo civil: comentado artigo por artigo. 2.ed., rev. e atual. Salvador, BA: JusPODIVM, 2017 p 1577

13 BRASIL. Código de Processo Civil 
$11 / 03 / 2011){ }^{14}$

Acredito que o entendimento do STF seja equivocado pois os tribunais somente estariam vinculados às decisões do da Suprema Corte no caso de essas consubstanciarem o microssistema de precedentes com eficácia vinculante, o que não é o caso. Infelizmente, julgados como esse são cada vez mais comuns, e demonstram uma tendência dos Tribunais Superiores de acatar e criar teses defensivas, e uma tentativa de diminuir por meios oblíquos a demanda de trabalho a qual são submetidos.

Além de que, a exemplo dos demais precedentes obrigatórios estudados nesse artigo, o precedente em comento pode ser superado, principalmente se apresentado nova tese que não fora utilizada quando do julgamento do incidente de arguição de inconstitucionalidade.

Como dito alhures tanto a doutrina quanto a jurisprudência e o próprio texto legal buscam cada vez mais prestigiar a reserva de plenário. Dessa feita é importante saber do que se trata tal reserva.

A reserva de plenário está prevista no art.97 CF/88, o artigo prevê que quando a arguição de inconstitucionalidade chegar aos tribunais, seja através de recursos, competência originária ou remessa necessária, apenas o plenário ou órgão especial terá competência para declarar a inconstitucionalidade. ${ }^{15}$ A razão disso é uniformizar o entendimento do tribunal com relação à constitucionalidade, exige-se o plenário ou órgão especial, pois deixar o ônus decisório por conta das turmas provocaria insegurança jurídica na medida em que as turmas poderiam divergir seu entendimento uma das outras. Uma ressalva a que ser feita, o Supremo Tribunal Federal decidiu que, quando a matéria já ter sido analisada pelo pleno ou por órgão especial, a turma do tribunal será competente para julgar o incidente de arguição de inconstitucionalidade, eis a transcrição da ementa do julgado:

STF - "Inconstituiconalidade - Incidente - Deslocamento do Processo para o órgão especial ou para o Pleno - Desnecessidade. Versando a controvérsia sobre ato normativo já declarado inconstitucional pelo guardião maior da Carta Política da República - o Supremo Tribunal Federal - descabe o deslocamento previsto no art.97 do referido Diploma maior. O julgamento de plano pelo órgão fracionado homenageia não só a racionalidade, como também implica interpretação teleológica do art.97 em comento, evitando a burocratização dos atos judiciais no que nefasta ao princípio da economia e da celeridade. A razão e ser do preceito está na necessidade de evitar-se que órgãos fracionados apreciem, pela primeira vez, a pecha de inconstitucionalidade arguida em relação a um certo ato normativo" (RTJ 162/765). ${ }^{16}$

Contudo, exceção existe à reserva de plenário, qual seja a declaração de

14 NEVES, Daniel Amorim Assumpção. Novo código de processo civil: comentado artigo por artigo. 2.ed., rev. e atual. Salvador, BA: JusPODIVM, 2017 p. 1580

15 ARAÚJO, Luiz Alberto David; NUNES JÚNIOR, Vidal Serrano. Curso de direito constitucional. 17. ed. São Paulo: Verbatim, 2013 p 64

16 MORAES, Alexandre de. Constituição do Brasil interpretada e legislação constitucional. 9. ed. São Paulo: Atlas, 2013 p. 1386 
constitucionalidade da lei ou ato normativo impugnado.

A previsão de rejeição do incidente contida no art.949 do Novo CPC diz respeito exclusivamente à decisão pela inadmissibilidade (não cabimento) quanto à decisão de improcedência (declaração de constitucionalidade). Não se estranhe a afirmação de que o órgão colegiado pode julgar o mérito do incidente, desde que declare a constitucionalidade da norma, já que para tal decisão há competência do órgão fracionário. O que não se admite, nos termos do art.97 da CF, é a declaração de inconstitucionalidade por tal órgão judiciário. ${ }^{17}$

O que justifica isso é o fato de que toda lei promulgada se presume constitucional, por se tratar de uma presunção iuris tantun, é cabível a discussão da constitucionalidade. Mas por se presumir constitucional é dado aos órgãos fracionários reconhecerem a sua constitucionalidade de forma a não ofender a ordem constitucional entabulada no art.97 CF/88.'

Interessante polêmica existe quanto à recorribilidade das decisões proferidas pelo pleno ou órgão especial que declara a norma constitucional ou inconstitucional. Os que entendem que por se tratar de questão prejudicial a lide, a discussão de inconstitucionalidade não deve ser entendida como causa, e por essa razão não seria cabível a interposição de recurso especial ou extraordinário em face da decisão que verse sobre a validade constitucional da norma, como expoente dessa doutrina encontra-se Daniel Amorim Assumpção Neves, o qual ensina que:

Entendo que essa decisão colegiada do órgão fracionário não é recorrível por recurso especial ou extraordinário porque nesse caso não há julgamento e qualquer causa, condição para o cabimento dos recursos excepcionais. Para não dizer que a decisão é irrecorrível, é cabível o recurso de embargos de declaração. Tal conclusão, entretanto, parte da premissa do clássico conceito de "causa", que aparentemente foi superado pela previsão do art.987, caput, do Novo CPC, que prevê o cabimento de recurso especial e extraordinário contra o acórdão que julgar o IRDR (incidente de resolução de demandas repetitivas). No caso do incidente de arguição de inconstitucionalidade não há previsão como essa, mas a partir do momento em que se alarga o conceito de "causa" para que o dispositivo legal possa ser considerado constitucional, o cabimento dos recursos excepcionais do acórdão que julga o incidente ora analisado passa a ser mais palatável. ${ }^{18}$

Não assiste razão o pensamento do respeitável jurista Daniel Neves, pois os tribunais de sobreposição existem justamente para dirimir controvérsias relacionadas ao controle de legalidade e constitucionalidade. Por não se tratar de uma causa stricto sensu, o tribunal não avaliará as questões de fato relativas à demanda. Entretanto, são competentes para firmar jurisprudência no que tange a legalidade ou constitucionalidade discutidos no incidente.

Soma-se o fato de que um outro tribunal a julgar semelhante demanda adote um entendimento divergente. Nesse caso não ter-se-á uniformização da jurisprudência, antes, pelo 17 NEVES, Daniel Amorim Assumpção. Novo código de processo civil: comentado artigo por artigo. 2.ed., rev. e atual. Salvador, BA: JusPODIVM, 2017 p.1579

18 NEVES, Daniel Amorim Assumpção. Manual de direito processual civil: volume único. 9. ed., rev., e atual. São Paulo: Método, 2017 
contrário, haverá conflito de entendimento, o que por sua vez cria uma situação de desigualdade entre os jurisdicionados, o que fere de morte o princípio da isonomia. Por essa razão é de bom entender que às partes é dado a possibilidade de recorrer, não só em razão de alterar o resultado da decisão, mas também para garantir uniformidade da jurisprudência e garantir isonomia entre as pessoas de diferentes Estados, ou regiões do país.

\section{INCIDENTE DE RESOLUÇÃO DE DEMANDAS REPETITIVAS ESPECIAL E EXTRAORDINÁRIO}

\section{O Incidente de Resolução de Demandas Repetitivas previsto no art.1.036CPC/15 ${ }^{19}$,} não foi inaugurado com o Novo Código, tendo por corresponde parcial os arts. 543-B; §.1 $1^{\circ}$ e $543-$ $\mathrm{C} \S \S 1 .^{\circ}$ e $2 .^{\circ}$ do revogado $\mathrm{CPC} / 73 .{ }^{20}$ Atualmente o mesmo artigo disciplina a competência do

\section{BRASIL. Código de Processo Civil.}

Art. 1.036. Sempre que houver multiplicidade de recursos extraordinários ou especiais com fundamento em idêntica questão de direito, haverá afetação para julgamento de acordo com as disposições desta Subseção, observado o disposto no Regimento Interno do Supremo Tribunal Federal e no do Superior Tribunal de Justiça.

$\S 1$ o O presidente ou o vice-presidente de tribunal de justiça ou de tribunal regional federal selecionará 2 (dois) ou mais recursos representativos da controvérsia, que serão encaminhados ao Supremo Tribunal Federal ou ao Superior Tribunal de Justiça para fins de afetação, determinando a suspensão do trâmite de todos os processos pendentes, individuais ou coletivos, que tramitem no Estado ou na região, conforme o caso.

§ $20 \mathrm{O}$ interessado pode requerer, ao presidente ou ao vice-presidente, que exclua da decisão de sobrestamento e inadmita o recurso especial ou o recurso extraordinário que tenha sido interposto intempestivamente, tendo o recorrente o prazo de 5 (cinco) dias para manifestar-se sobre esse requerimento.

$\S 3^{\circ} \mathrm{Da}$ decisão que indeferir o requerimento referido no $\S 2^{\circ}$ caberá apenas agravo interno.

$\S 40$ A escolha feita pelo presidente ou vice-presidente do tribunal de justiça ou do tribunal regional federal não vinculará o relator no tribunal superior, que poderá selecionar outros recursos representativos da controvérsia.

$\S 50$ O relator em tribunal superior também poderá selecionar 2 (dois) ou mais recursos representativos da controvérsia para julgamento da questão de direito independentemente da iniciativa do presidente ou do vice-presidente do tribunal de origem.

§ 6o Somente podem ser selecionados recursos admissíveis que contenham abrangente argumentação e discussão a respeito da questão a ser decidida.

20 BRASIL. Código de Processo Civil 1973.

Art.543-B. Quando houver multiplicidade de recursos com fundamento em idêntica controvérsia, a análise da repercussão geral será processada nos termos do Regimento Interno do Supremo Tribunal Federal, observado o disposto neste artigo.

$\S 1$. $^{\circ}$ Caberá ao Tribunal de origem selecionar um ou mais recursos representativos a controvérsia e encaminhá-los ao Supremo Tribunal Federal, sobrestado os demais até o pronunciamento definitivo da Corte.

$\S 2 .^{\circ}$ Negada a existência de repercussão geral, os recursos sobrestados considerar-se-ão automaticamente não admitidos.

§ 3. Julgado o mérito do recurso extraordinário, os recursos sobrestados serão apreciados pelos Tribunais, Turmas de Uniformização ou Turmas Recursais, que poderão declará-los prejudicados ou retratar-se.

$\S 4 .^{\circ}$ Mantida a decisão e admitido o recurso, poderá o Supremo Tribunal Federal, nos termos do Regimento Interno, cassar ou reformar, liminarmente, o acórdão contrário à orientação firmada.

$\S 5 .^{\circ} \mathrm{O}$ regimento Interno do Supremo Tribunal Federal disporá sobre as atribuições dos Ministros, das Turmas e de outros órgãos, na análise da repercussão geral.

Art.543-C. Quando houver multiplicidade de recursos com fundamento em idêntica questão de direito, o recurso especial será processado nos termos deste artigo.

$\S 1 .^{\circ}$ Caberá ao presidente do tribunal de origem admitir um ou mais recursos representativos da controvérsia, os quais serão encaminhados ao Superior Tribunal de Justiça.

$\S 2 .^{\circ}$ Não adotada a providência descrita no $\S 1 .^{\circ}$ deste artigo, o relator no Superior Tribunal de Justiça, ao identificar que sobre a controvérsia já existe jurisprudência dominante ou que a matéria já está afeta ao colegiado, poderá 
Supremo Tribunal Federal e do Supremo Tribunal de Justiça, mas na essência manteve o que era disposto no revogado Código.

Para que esse incidente seja instaurado é necessário que haja multiplicidade de recursos extraordinários ou especiais em um mesmo tribunal de justiça, ou tribunal federal. Antes de aprofundar os estudos sobre o incidente propriamente dito, é de bom alvitre que se tenha em mente a natureza de recurso extraordinário e especial. Sobre o tema a doutrina ensina que:

São recursos - o extraordinário e o especial - denominados de estrito direito, através dos quais se colima o prevalecimento da ordem constitucional (no extraordinário) e a unidade e a integridade do direito federal, infraconstitucional, em todo o território nacional (no especial). ${ }^{21}$

Feito esse breve escorço doutrinário, podemos passar ao debate do tema propriamente dito. Quando o incidente de demandas repetitivas se der no bojo de um recurso extraordinário ou especial, o presidente ou vice-presidente do tribunal de segunda instância escolherá 2 (dois) ou mais recursos representativos da controvérsia e os encaminhará ao Tribunal de Sobreposição competente, tendo a discussão por objeto o controle de constitucionalidade os recursos terão por destino o Supremo Tribunal Federal, enquanto se o debate versar sobre o controle de legalidade terá por destino o Supremo Tribunal de Justiça.

Em que pese o art.1.036 CPC/15 não faça menção expressa à repercussão geral como o fez o revogado $\mathrm{CPC} / 73$, no entanto essa é uma exigência implícita. É implícito pois para que o incidente seja admissível é imprescindível a repetibilidade de casos discutindo a mesma demanda nos tribunais de sobreposição, os quais por sua vez fazem um controle prévio de admissibilidade dos recursos extraordinários ou especais, sendo um dos critérios a repercussão

\footnotetext{
determinar a suspensão, nos tribunais de segunda instância, dos recursos nos quais a controvérsia esteja estabelecida. $\S 3 .^{\circ} \mathrm{O}$ relator poderá solicitar informações, a serem prestados no prazo de quinze dias, aos tribunais federais ou estaduais a respeito da controvérsia.

$\S 4 .^{\circ} \mathrm{O}$ relator, conforme dispuser o regimento interno do Superior Tribunal de Justiça e considerando a relevância da matéria, poderá admitir manifestação de pessoas, órgãos ou entidades com interesse na controvérsia.

$\S 5 .^{\circ}$ Recebidas as informações e, se for o caso, após cumprido o disposto no $§ 4 .^{\circ}$ deste artigo, terá vista o Ministério Público pelo prazo de quinze dias.

$\S 6^{\circ}{ }^{\circ}$ Transcorrido o prazo para o Ministério Público e remetida cópia do relatório aos demais Ministros, o processo será incluído em pauta na seção ou na Corte Especial, devendo ser julgado com preferência sobre os demais feitos, ressalvados os que envolvam réu preso e os pedidos de habeas corpus.
}

$\S 7 .^{\circ}$ Publicado o acórdão do Superior Tribunal de Justiça, os recursos especiais sobrestados na origem:

I - terão seguimento denegado na hipótese de o acórdão recorrido coincidir com a orientação do Superior Tribunal de Justiça; ou

II - serão novamente examinados pelo tribunal de origem na hipótese de o acórdão recorrido divergir da orientação do Superior Tribunal de Justiça.

$\S 8 .^{\circ} \mathrm{Na}$ hipótese prevista no inciso II do $\S 7 .^{\circ}$ deste artigo, mantida a decisão divergente pelo tribunal de origem, farse-á o exame de admissibilidade do recurso especial.

§9..$^{\circ}$ O Superior Tribunal de Justiça e os tribunais de segunda instância regulamentarão, no âmbito de suas competências, os procedimentos relativos ao processamento e julgamento do recurso especial nos casos previstos neste artigo.

21 ALVIM, Eduardo Arruda. Direito processual civil. 4. ed. ref., atual. e ampl. São Paulo: Revista dos Tribunais, 2012 
geral dos casos que lhes são apresentados.

Além da repercussão geral supracitada a doutrina elenca outros pré-requisitos para a admissibilidade do Incidente de Resolução de Demandas Repetitivas (IRDR), quais sejam:

A instauração do incidente de resolução de demandas repetitivas exige a coexistência dos seguintes pressupostos ou requisitos:

a) Constatação da existência de vários processos (dezenas, centenas, milhares) que contenham controvérsia sobre a mesma questão unicamente de direito, como as ações propostas por usuários de plano de saúde, fundadas na tese de que o réu não poderia majorar o valor das mensalidades, pelo fato de os usuários terem atingido determinada idade; as ações propostas contra empresas concessionárias de serviço público, fundadas na tese de ilegalidade da majoração da tarifa de energia elétrica, apenas para exemplificar;

b) Constatação da existência de risco à isonomia, decorrente da possibilidade de as ações individuais que se encontram em curso, versando sobre a mesma matéria, serem decididas de forma diferente, acarretando injustiça para alguns autores;

c) Constatação da existência de risco à segurança jurídica. A lei não predefiniu a quantidade de ações individuais já propostas que justificaria a instauração do incidente de resolução de demandas repetitivas. A quantidade de ações não é critério único para a instauração, pois a efetiva repetição de processos deve estar associada à constatação do risco de ofensa à isonomia e à segurança jurídica. ${ }^{22}$

Uma observação há que ser feita no que diz respeito ao requisito da repetitividade das demandas. O Tribunal de Sobreposição poderá se for caso, admitir o recurso, especial ou extraordinário, e postergar o seu julgamento com o fito de aguardar que novos recursos que versem sobre a mesma questão lhe seja apresentado, nesse sentido Nelson Nery disserta que:

Contudo, deixa aberta a possibilidade de o tribunal, ao receber o RE para aferir a admissibilidade, aguardar a interposição de outros com a mesma tese, ao sentir que existe essa possibilidade. O RISTF 328 caput é expresso no sentido de que o próprio STF, "protocolado ou distribuído recurso cuja questão for suscetível de reproduzir-se em múltiplos feitos", comunicará o fato aos tribunais locais para que procedam de acordo com o CPC 1036 e ss. Essa circunstância de o tribunal local poder "aguardar" a interposição de outros RE, em casos em que a tese provavelmente se repetirá, pode configurar negativa de vigência da garantia constitucional da celeridade (CF 5. ${ }^{\circ}$ LXXVIII) ${ }^{23}$

O que for decidido em sede de IRDR fará coisa julgada em relação aos recursos que deram origem ao incidente bem como produzirá efeito vinculante em relação a todos os órgãos do Poder Judiciário, ou seja, o precedente resultante do julgamento será considerado um precedente vinculante. Dessa feita produzirá os mesmos efeitos práticos do incidente de assunção de competência.

22 MONTENEGRO FILHO, Misael. Curso de direito processual civil. 12. Rio de Janeiro Atlas 2016

23 NERY JUNIOR, Nelson; NERY, Rosa Maria de Andrade. Código de processo civil comentado. 16. ed., rev., atual. e ampl. São Paulo: Revista dos Tribunais, 2016 p. 2208 
Questão interessante é possibilidade de desistência do recurso que deu origem ao Incidente de Resolução de Demandas Repetitivas. Por se tratar de um recurso que originariamente produziria efeitos apenas inter partes é possível que uma das partes desista do recurso. Contudo essa desistência não tem o condão de prejudicar a análise do incidente.

Dada a natureza jurídica do instituto da desistência do recurso, vale dizer, de negócio jurídico unilateral não receptício, sua eficiência é plena, independe da concordância ou anuência do recorrido e dispensa homologação judicial. Daí por que o recorrente que interpôs RE e/ou REsp pode dele desistir, ainda que tenha sido empregado ao seu recurso excepcional o rito do recurso repetitivo (CPC 1036). Isto porque o caso que será julgado pelo STF e/ou STJ como recurso repetitivo tem, como matéria de fundo, lide individual que encerra discussão sobre direito subjetivo. ${ }^{24}$

Isso se justifica pelo fato de que apesar de o incidente ser instaurado em um causa concreta, envolvendo, em um primeiro momento, apenas os interesses dos litigantes, a decisão do incidente produzirá efeitos erga omnes. Ou seja, a questão discutida no incidente analisado pelo STJ ou STF é interessante para todo o ordenamento jurídico brasileiro, pois essa servirá para balizar as próximas decisões judiciais.

\section{SEGURANÇA JURÍDICA}

A muito se fala sobre segurança jurídica, discute-se qual a importância dessa dentro do ordenamento jurídico brasileiro, chegando alguns ao ponto de dizer que não se faz necessária sua observância, uma vez que, ao menos em tese essa pode acabar por engessar a prestação estatal em especial a judiciária.

Para aprofundar a análise sobre a pertinência ou não de respeitar o princípio da segurança jurídica, é necessário que se conceitue o que é segurança jurídica. Para Canotilho, segurança jurídica é:

Em geral, considera-se que a segurança jurídica - garantia de estabilidade jurídica, segurança de orientação e realização do direito - enquanto a proteccção da confiança se prende mais com as componentes subjectivas da segurança, designadamente a calculabilidade e previsibilidade dos indivíduos em relação aos efeitos jurídicos dos actos públicos $\{\ldots\}$.

Deduz-se já que os postulados da segurança jurídica e da protecç̧ão da confiança são exigíveis perante qualquer acto de qualquer poder - legislativo, executivo e judicial. ${ }^{25}$

Note-se que para Canotilho, a segurança jurídica é uma norma, que por ter alta carga valorativa classifica-se como princípio, uma vez que determina um fim a ser alcançado.

24 NERY JUNIOR, Nelson; NERY, Rosa Maria de Andrade. Código de processo civil comentado. 16. ed., rev., atual. e ampl. São Paulo: Revista dos Tribunais, 2016 p. 2208

25 CANOTILHO, J. J. Gomes. Direito constitucional e teoria da constituição. 6. ed. Coimbra: Almedina, 2002 p. 257 
Entretanto, esse entendimento não é uníssono na doutrina, sendo que entre a doutrina brasileira existem aqueles que defendem que a segurança jurídica não é uma norma propriamente dita, mas sim, um conceito, nesse sentido Humberto Ávila disserta que:

É preciso frisar também que a segurança jurídica, quando analisada sob essa perspectiva, não é uma norma, mas sim um conceito ou um elemento de um conceito. Sob esse viés, ela é definida como uma ideia "supraordenadora" (übergeordneterIdee) ou como um "sobreconceito" (Überbegriff). Note-se que, nesse aspecto, a segurança jurídica é um elemento da metalinguagem doutrinária, e não uma norma sobre a qual ela verte. ${ }^{26}$

A segurança jurídica, em que pese tenha uma carga conceitual não deve ser entendida apenas como conceito ou "sobreconceito" como quer Ávila, pois é um dos princípios basilares de qualquer Estado de Direito Democrático. Sendo inclusive, uma obrigação do Estado, zelar pela segurança jurídica, a ponto de a doutrina administrativista mais clássica considerar a segurança jurídica como um dos princípios que regem a administração pública. ${ }^{27}$ Para Hely Lopes Meirelles, a segurança jurídica no combate entre normas, se sobrepõe ao próprio princípio da legalidade, sendo este, um dos principais princípios da administração pública, diz o renomado autor que:

\begin{abstract}
Alterar esse estado de coisas, sob o pretexto de restabelecer a legalidade, causará mal maior do que preservar o status quo. Ou seja, em tais circunstâncias, no cotejo dos dois subprincípios do Estado de Direito, o da legalidade e o da segurança jurídica, este último prevalece sobre o outro, como imposição da justiça material. ${ }^{28}$
\end{abstract}

Dessa feita, a segurança jurídica deve ser considerada um princípio norteador da conduta estatal, o que inclui o Judiciário. Não é sem razão que a segurança jurídica recebeu o status de princípio constitucional, sendo que a doutrina entende que a sua previsão legal se encontra no preâmbulo da Constituição Federal ${ }^{29}$. A segurança jurídica se faz necessária para proteger os interesses dos cidadãos, garantindo-lhes isonomia, e previsibilidade.

A segurança jurídica gera isonomia na medida em que todos os jurisdicionados sabem o que esperar e que terão um tratamento igualitário, de modo semelhantes aos dos demais que se encontravam na mesma situação. Ou seja, a lei em sentido lato e as decisões jurisdicionais são aplicadas a todos de forma igualitária, de forma que a prestação jurisdicional se dê de forma justa e não arbitrária.

Pela mesma razão, a segurança jurídica gera previsibilidade, na medida em que as pessoas conseguem avaliar quais serão as consequências de suas condutas. Este último fator tem um viés econômico, uma vez que quanto maior a previsibilidade, menores são os riscos. E, quanto

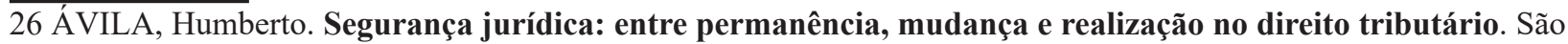
Paulo: Malheiros, 2011 p. 107

27 MEIRELLES, Hely Lopes. Direito administrativo brasileiro. 40. ed. São Paulo: Malheiros, 2014 p. $103 / 105$

28 MEIRELLES, Hely Lopes. Direito administrativo brasileiro. 40. ed. São Paulo: Malheiros, 2014 p. 104/105

29 ÁVILA, Humberto. Segurança jurídica: entre permanência, mudança e realização no direito tributário. São Paulo: Malheiros, 2011 p. 33
} 
menores os riscos maiores tendem a ser os investimentos no país, uma vez que os investidores se sentem seguros para investir. De forma que, entre os contabilistas e tributaristas é comum a expressão "o Brasil é o único país do mundo onde não se tem certeza do passado", em referência à insegurança jurídica comum ao Direito Tributário.

Portanto, a observância do princípio da segurança jurídica é imprescindível para a garantia de um Estado Democrático de Direito Isonômico que objetiva crescer econômica e socialmente.

\section{SOLIPSISMO JUDICIAL}

O solipsismo judicial é fruto do poder discricionário do juiz pós positivista. Isso porque na atualidade não existem mais “juízes boca da lei”, nossa Constituição Federal, e nossos Diplomas infraconstitucionais conferiram ao juiz o poder de discricionariedade, dessa forma o juiz passou a decidir de acordo com o seu livre convencimento motivado.

Dessa forma, o juiz não mais se limita a repetir as palavras da lei, e aplica-la sem fazer qualquer interpretação que não seja a literal. O julgador ao aplicar a lei deve analisa-la dentro de um contexto fático e jurídico, de forma a extrair o real significado da norma, e de modo que a aplicação dessa não fira um direito ou princípio fundamental.

Mas, não é incomum que em um mesmo caso concreto várias normas entrem em rota de colisão, criando embaraços quanto à sua aplicação. Quando essas normas são regras, a doutrina solucionou o problema de forma bastante simples, criou critérios para decidir qual norma ser aplicada ao caso concreto, sendo esses critérios: hierárquico; especialidade e; norma mais recente.

O grande problema é quando essas normas de se traduzem em princípios, sejam esses de ordem constitucional ou legal. Quando o conflito se dá entre princípios não é possível aplicar os critérios de derrogação atinentes às regras. Nesse caso é necessário fazer um juízo de valor, escolher a qual preterir para que o outro ganhe posição de destaque.

Por ser uma análise subjetiva, essa aumenta o poder discricionário do magistrado, de tal forma que esse pode acabar por decidir conforme suas próprias convicções relegando a segundo plano a profunda análise do direito, ora debatida na lide.Nesse sentido LenioStreck critica o mau uso dessa discricionariedade por parte dos juízes ao afirmar que:

Há no direito uma palavra técnica para se referir à escolha: discricionariedade e, quiçá arbitrariedade. Portanto, quando um jurista diz que "o juiz possui poder discricionário" para resolver os "casos difíceis", o que quer afirmar é que, diante de várias possibilidades de solução do caso, o juiz pode escolher aquela que melhor lhe convier...! ${ }^{30}$

Para esse autor, a discricionariedade do juiz não pode se confundir com

30 STRECK, Lenio Luiz. O que é isto: decido conforme minha consciência? . 3. ed. Porto Alegre: Livraria do Advogado, 2012 p. 106 
arbitrariedade. Mesmo no choque entre princípios o magistrado tem que ter um olhar atento ao que o ordenamento jurídico, a se entender doutrina, lei, jurisprudência e precedentes vem adotando como referencial em casos da mesma natureza, e após essa análise minuciosa o juiz deve decidir de forma mais acertada, ouçamo-lo:

E esse ponto é absolutamente fundamental! Isso porque é o modo como se compreende esse sentido do direito projetado pela comunidade política (que é uma comunidade - virtuosa - de princípios) que condicionará a forma como a decisão jurídica será realizada de maneira que, somente a partir desse pressuposto falar em respostas corretas ou respostas adequadas.

Sendo mais claro, toda decisão deve se fundar em um compromisso (précompreendido). Esse compromisso passa pela reconstrução da história institucional do direito - aqui estamos falando, principalmente, dos princípios enquanto indícios formais dessa reconstrução - e pelo momento de colocação do caso julgado dentro da cadeia da integridade do direito. ${ }^{31}$

Essa postura solipsista do magistrado pautada em uma suposta ponderação de princípios, os juízes ativistas justificam seus atos baseados na teoria dos princípios, criada por Humberto Ávila. Dizem que essa teoria difere princípios de regras e que no conflito entre esses, um deve ser preterido em razão do outro a fim de causar a menor lesão possível aos direitos e garantias fundamentais de uma das partes envolvidas na lide.

Entretanto, assim como LenioStreck defende, Humberto Ávila advoga ideia de que mesmo o conflito entre princípios deve ter por norte certos critérios, sob pena de ser cometido abuso de direito do julgador do caso, nesse sentido:

É preciso estruturar a ponderação com a inserção de critérios. Isso fica evidente quando se verifica que os estudos sobre a ponderação com os postulados de razoabilidade e direcionar a ponderação mediante utilização dos princípios constitucionais fundamentais. Nesse aspecto, a ponderação, como mero método ou ideia geral despida de critérios formais ou materiais, é muito mais ampla que os postulados da proporcionalidade e da razoabilidade. ${ }^{32}$

É de suma importância essa consideração do citado jurisconsulto, uma vez que os juízes ativistas justificam suas decisões lastreadas pela teoria dos princípios, cujo seu maior percursor é Humberto Ávila. O próprio criador da teoria assevera que não se pode olvidar de critérios quando da escolha da preponderância de um princípio sobre outro. Entre os possíveis critérios está a observância da jurisprudência majoritária.

Entretanto, como em muitos dos casos é difícil averiguar qual o entendimento predominante dos tribunais acerca de uma determinada situação, seja por ter poucos julgados discutindo o tema, seja por grande número de decisões divergentes; é de bom alvitre que se tenha

31 STRECK, Lenio Luiz. O que é isto: decido conforme minha consciência? . 3. ed. Porto Alegre: Livraria do Advogado, 2012 p. 106

32 ÁVILA, Humberto Bergmann. Teoria dos princípios: da definição à aplicação dos princípios jurídicos. 13. ed., rev. e ampl. São Paulo: Malheiros, 2012 p 164/165 
outros meios de descobrir qual é a jurisprudência a ser aplicada de forma a não deixar totalmente discricionária a decisão do magistrado de primeiro grau. Uma solução proposta pelo Código de Processo Civil de 2015 foi a criação do microssistema de precedentes.

\section{CONCLUSÃO}

A insegurança jurídica causada pelos juízes solipsistas é uma celeuma que a tempos aflige o Brasil. Com o fito de amenizar os devastadores efeitos do ativismo judicial os tribunais brasileiros de sobreposição, em especial o STF, buscaram criar mecanismos que uniformizassem a jurisprudência, evitando assim, a proliferação de decisões conflitantes de forma restaurar a confiança do povo brasileiro no Poder Judiciário.

No mesmo sentido o Poder Legislativo ainda sobre a égide do Código de Processo Civil de 1973, transformou em lei alguns dos entendimentos do Superior Tribunal Federal, alterando assim de forma sintomática o revogado Código de Processo Civil. Contudo, isso não bastou, por essas e outras razões o legislador brasileiro deu origem ao Código de Processo Civil de 2015.

O Novel Código, ampliou e perfectibilizou microssistema de precedentes, de forma a dar coesão aos meios uniformizadores da jurisprudência. O microssistema de precedentes, não engessa a liberdade de decisão do magistrado, que pode superar o precedente desde de que fundamente que esse não é aplicável ao caso que lhe fora apresentado, ou que por outra razão merece ser superado.

Entretanto, os precedentes obrigatórios impedem que o juiz julgue ao seu bel prazer, sacando "princípios coringas" para fundamentar suas decisões. Ou seja, os precedentes obrigatórios da forma como estão dispostos no Código de Processo Civil de 2015, tem o condão de dar efetividade ao princípio da segurança jurídica brasileira, e consequentemente, restaurar a credibilidade dos jurisdicionados, inclusive dos investidores internacionais no Poder Judiciário Brasileiro.

\section{REFERÊNCIAS}

ALVIM, Eduardo Arruda. Direito processual civil. 4. ed. ref., atual. e ampl. São Paulo: Revista dos Tribunais, 2012

\section{ARAÚJO, Luiz Alberto David; NUNES JÚNIOR, Vidal Serrano. Curso de direito constitucional. 17. ed. São Paulo: Verbatim, 2013 p 64}

ÁVILA, Humberto Bergmann. Teoria dos princípios: da definição à aplicação dos princípios jurídicos. 13. ed., rev. e ampl. São Paulo: Malheiros, 2012

. Segurança jurídica: entre permanência, mudança e realização no direito tributário. São Paulo: Malheiros, 2011 
BULOS, UadiLammêgo. Curso de direito constitucional. 5. ed., ref. e atual. São Paulo: Saraiva, 2010

BRASIL, Código de Processo Civil, Lei 13.105/2015.

CANOTILHO, J. J. Gomes. Direito constitucional e teoria da constituição. 6. ed. Coimbra: Almedina, 2002 p. 257

KELSEN, Hans; Teoria pura do direito. Tradução MACHADO, João Batista - $8^{\text {a }}$. Ed. - São Paulo: Editora WMF Martins Fontes, 2009.

MEIRELLES, Hely Lopes. Direito administrativo brasileiro. 40. ed. São Paulo: Malheiros, 2014 p $103 / 105$

FILHO, Misael. Curso de direito processual civil. 12. Rio de Janeiro Atlas 2016.

NEVES, Daniel Amorim Assumpção. Manual de direito processual civil: volume único. 9. ed., rev., e atual. São Paulo: Método, 2017.

. Novo código de processo civil: comentado artigo por artigo. 2.ed., rev. e atual.

Salvador, BA: JusPODIVM, 2017.

NERY JUNIOR, Nelson; NERY, Rosa Maria de Andrade. Código de processo civil comentado. 16. ed., rev., atual. e ampl. São Paulo: Revista dos Tribunais, 2016.

PINHEIRO, Paulo Eduardo D'Arce et al. Curso de processo civil completo. São Paulo: Revista dos Tribunais, 2017.

THEODORO JÚNIOR, Humberto. Curso de direito processual civil: volume 3: execução forçada: cumprimento de sentença, execução de títulos extrajudiciais, processos nos tribunais, recursos, direito intertemporal. 50. ed., rev., atual., ampl. Rio de Janeiro: Forense, Gen, 2017.

STRECK, Lenio Luiz. O que é isto: decido conforme minha consciência? . 3. ed. Porto Alegre: Livraria do Advogado, 2012.

Recebido em: 23/04/2019.

Aprovado em: 30/04/2019. 